\title{
Experimental infection of white spot syndrome virus in freshwater crayfish Pacifastacus leniusculus
}

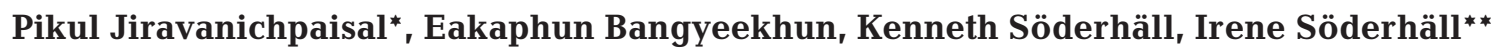

Department of Comparative Physiology, Evolutionary Biology Centre, Uppsala University, Norbyvägen 18A, 752 36 Uppsala, Sweden

\begin{abstract}
The signal freshwater crayfish Pacifastacus leniusculus was found to be susceptible to infection with white spot syndrome virus (WSSV). Histopathological observations of various tissues of virus-injected crayfish showed similar symptoms to those from WSSV-infected penaeid shrimp, but no appearance of white spots on the cuticle or reddish body colour were observed, although these are the prominent gross signs of white spot disease in shrimp. A gene probe for detecting WSSV was developed in order to detect the virus in affected cells and tissues using in situ hybridisation. Strong signals were observed in cells of virus-injected crayfish, but not in control-injected crayfish. The number of granular haemocytes in virus-injected crayfish was significantly higher than in sham-injected and non-injected crayfish from Days 5 to $8(p \leq 0.05)$ and Days 3 to 8 ( $p<0.01)$ postinjection, respectively. The proportion of granular haemocytes in virus-injected crayfish was also significantly higher than in sham-injected controls from Days 3 to 8 ( $\mathrm{p}<0.01)$. These results indicate that WSSV has a significant effect on the proportion of different haemocyte types in the freshwater crayfish.
\end{abstract}

KEY WORDS: White spot syndrome virus · WSSV · Crayfish • Pacifastacus leniusculus $\cdot$ In situ hybridisation

Resale or republication not permitted without written consent of the publisher

White spot disease is one of the most disastrous in shrimp culture, having reduced shrimp production extensively worldwide. Mortality rates are usually very high and cumulative mortality can reach $100 \%$ within 3 to $10 \mathrm{~d}$ from the onset of visible gross signs (Chou et al. 1995, Wongteerasupaya et al. 1995). White spot

\footnotetext{
*Present address: Marine Biotechnology Research Unit, National Centre for Genetic Engineering and Biotechnology (BIOTEC), National Science and Technology Development Agency (NSTDA), Ministry of Science, Technology and Environment, Bangkok 10400, Thailand

${ }^{* *}$ Corresponding author. E-mail: irene.soderhall@ebc.uu.se
}

disease has been reported from several Asian countries since the early 1990s (Inouye et al. 1994, Momoyama et al. 1994, Nakano et al. 1994, Chou et al. 1995, Flegel et al. 1995, Huang et al. 1995, Wongteerasupaya et al. 1995, Mohan et al. 1998, Park et al. 1998, Y. G. Wang et al. 1999), and more recently from South America and from the south-eastern coast of the USA (Lightner et al. 1997, Lo et al. 1999, Q. Wang et al. 1999, 2000).

White spot syndrome virus (WSSV) is a rod-shaped crustacean virus (Takahashi et al. 1994, Chou et al. 1995, C. H. Wang et al. 1995, Lo et al. 1996, Y. G. Wang et al. 1999) with a wide geographic distribution and host range. All the major species of cultivated penaeid shrimp can be naturally infected by this virus (Inouye et al. 1994, Nakano et al. 1994, Chou et al. 1995, Wongteerasupaya et al. 1995, Lo et al. 1996, Flegel 1997, Lightner et al. 1997, Mohan et al. 1998, Nunan et al. 1998, Park et al. 1998, Q. Wang et al. 1999). In addition to penaeid species, both natural and experimental infections have also been reported in caridean shrimp (Exopalaemon orientalis and Macrobrachium rosenbergii), crayfish (Orconectes punctimanus), wild crabs (Calappa lophos, Portunus sanguinolentus, P. pelagicus, Charybdis sp., Helice tridens and Scylla serrata), wild lobsters (Panulirus sp.), palaemonidian pest shrimp, krill (Acetes sp.), planktonic copepods and pupae of an ephydridian insect (Chang et al. 1998, Kanchanaphum et al. 1998, Peng et al. 1998, Supamattaya et al. 1998, Y. C. Wang et al. 1998, Q. Wang et al. 2000).

The virus can be detected by the use of polymerase chain reaction (PCR), in situ hybridisation or monoclonal antibody assays (Kanchanaphum et al. 1998, Peng et al. 1998, Poulos et al. 2001). Thus, in recent years molecular probes have been developed as diagnostic tools and these are already being used for pathogen detection in commercial shrimp farms. 
The aim of the present study was to ascertain whether the freshwater signal crayfish Pacifastacus leniusculus is susceptible to WSSV infection. This species has been introduced in many European waters to replace native crayfish species that have been eradicated by the crayfish plague fungus (Söderhäll \& Cerenius 1999). Crayfish constitute a major part of the freshwater fauna and play an important ecological role. They are also useful laboratory models for the study of defence mechanisms among crustaceans. Therefore, a gene probe for detecting WSSV in crayfish was developed for further studies on virus-host interaction at the cellular level.

Materials and methods. Experimental animals: Freshwater crayfish Pacifastacus leniusculus were purchased from Berga Kräftodling, Södermanland, Sweden and maintained in tanks with running aerated water at $10^{\circ} \mathrm{C}$. Only healthy male intermolt crayfish were used for the experiments. Prior to the initiation of the experiments all crayfish were acclimated for $24 \mathrm{~h}$ at $20^{\circ} \mathrm{C}$ where the experiments were to be performed.

WSSV propagation: WSSV was propagated in vivo by inoculation of clarified gill tissue homogenates from previously naturally infected Penaeus monodon with prominent white spots on the cuticle. The homogenates were maintained in M199 medium in 15\% seawater at $-80^{\circ} \mathrm{C}$. WSSV from $P$. monodon was also propagated in crayfish. Gill tissues from 8 moribund crayfish (3 g) were collected, homogenised in $10 \mathrm{ml}$ of Leibovitz medium (L15) at $4^{\circ} \mathrm{C}$ and clarified by centrifugation at $10000 \times g$ for $30 \mathrm{~min}$ at $4^{\circ} \mathrm{C}$. The supernatant was then diluted 10 -fold with L15 medium. The same amount of gills from healthy crayfish was treated similarly and used as a control. The supernatants were divided into aliquots and stored at $-80^{\circ} \mathrm{C}$ until used. For infection experiments, an amount of $200 \mu \mathrm{l}$ from each dilution was injected via the base of the fourth walking leg of crayfish. The lowest effective dosage of the dilution that was able to kill crayfish within $10 \mathrm{~d}$ was selected for further studies.

DNA isolation: DNA was isolated from gills of both control and virus-infected crayfish using a DNA Isolation Kit (PURE GENE ${ }^{\circledR}$, Gentra Systems, Minneapolis, MN, USA) following the manufacturer's protocols. DNA concentration was determined by measuring absorbance at $260 \mathrm{~nm}$ using a visible UV spectrophotometer. DNA extracts were stored at $-20^{\circ} \mathrm{C}$.

PCR conditions: Specific WSSV primers were designed from a WSSV genomic sequence (GenBank accession No. AF178573). The primer sequences were 5'TTG ACG ACG ACT ATG ATG AC3' as the upstream primer and 5'GCT TAC GGA TTT ACA CCT CT3' as the downstream primer. PCR amplification was carried out in a $50 \mu \mathrm{l}$ volume containing primers (0.5 $\mu \mathrm{M}$ each), deoxynucleotide triphosphates $(200 \mu \mathrm{M}$ each), Taq polymerase (2.5 U per $50 \mu \mathrm{l}), \mathrm{MgCl}_{2}(1.5 \mathrm{mM})$ in PCR buffer (1×) and $100 \mathrm{ng}$ of a DNA template. The PCR amplification was performed in an automatic thermocycler (Perkin-Elmer Gene Amp PCR System 2400). The amplification program was as follows: initiation denaturation at $95^{\circ} \mathrm{C}$ for $5 \mathrm{~min}, 25$ cycles of denaturation at $95^{\circ} \mathrm{C}$ for $1 \mathrm{~min}$, annealing at $50^{\circ} \mathrm{C}$ for $30 \mathrm{~s}$ and polymerisation at $72^{\circ} \mathrm{C}$ for $1 \mathrm{~min}$, and final polymerisation at $72^{\circ} \mathrm{C}$ for $7 \mathrm{~min}$. A negative control using sterile distilled water instead of DNA template was included to monitor for possible contamination. After amplification, PCR products were analysed in $1 \%$ agarose gel, stained with ethidium bromide and visualised under UV illumination.

DNA cloning and sequencing: The amplified products were purified using GFX ${ }^{\mathrm{TM}}$ PCR DNA and a Gel Band Purification kit (Amersham, Uppsala, Sweden) and cloned into PCR 2.1-TOPO vector (Invitrogen, Groningen, The Netherlands) according to the manufacturer's protocol. Several clones derived from PCR amplifications were sequenced using dye terminator reactions (Perkin-Elmer) by an automated sequencer (ABI Prism 377 DNA Sequencer, Applied Biosystems, Foster City, CA, USA). The sequences were analysed using the BLAST search program (National Centre for Biotechnology International, Bethesda, MD, USA).

Probe preparation: The 1537 base pair DNA fragment of WSSV obtained from PCR amplification was randomly labelled with digoxigenin-11-deoxyuridine triphosphate using the High Prime DNA labelling kit (Boehringer Mannheim, Indianapolis, IN, USA) according to the manufacturer's protocol. Labelled DNA was visualised using alkaline phosphatase conjugated antidigoxigenin antibody and the reagents nitroblue tetrazolium and 5-bromo-4-chloro-3-indolyl-phosphate.

Histopathological studies and in situ hybridisation: The samples of sham-injected and virus-injected crayfish at Days 3 and 8 post-injection were fixed in Davidson fixative (Bell \& Lightner 1998) for histology and in situ hybridisation assay. All specimens were then dehydrated through a series of alcohol, cleared in xylene and finally embedded in paraffin wax. Tissue sections were prepared as previously described by Bell \& Lightner (1998) and stained with haematoxylin and eosin (H\&E) stain. Sections from the same tissues were used for in situ hybridisation assays. Briefly, after dewaxing and rehydration, the sections were incubated for $15 \mathrm{~min}$ at $37^{\circ} \mathrm{C}$ with $100 \mu \mathrm{l}$ of Proteinase K $\left(100 \mu \mathrm{g} \mathrm{ml}^{-1}\right)$ per slide. The slides were fixed in $0.4 \%$ formaldehyde for $5 \mathrm{~min}$ at $4^{\circ} \mathrm{C}$ and immersed in distilled water for $5 \mathrm{~min}$. Then, the sections were hybridised with $500 \mathrm{ng} \mathrm{ml} \mathrm{m}^{-1}$ of digoxigenin-labelled probe in $50 \mu$ of hybridisation buffer containing $1 \times$ Denhardt's solution, $10 \%$ dextran sulphate, $8 \times$ saline sodium citrate buffer and $50 \%$ formamide. After hy- 
bridisation, hybrids were detected using alkaline phosphatase-conjugated anti-digoxigenin Fab fragments according to Boehringer Mannheim's protocols. A positive hybridisation reaction produced a dark purple precipitate against the light green background of the counterstain (methyl green) and this appeared as black in black-and-white photographs.

Circulating haemocyte counts: The crayfish were divided into 3 groups of 8 . The viral challenge group was injected with $200 \mu \mathrm{l}$ of viral supernatant into the soft tissue at the base of the fourth walking leg using a sterile syringe with a needle ( $23 \mathrm{G} 1,0.6 \times 25 \mathrm{~mm}$ ). The sham-injected control group received the same volume of non-viral supernatant. The third group of crayfish did not receive an injection. All crayfish were kept under the same conditions. Circulating haemocytes were counted from the virus-injected and shaminjected control group on Days 1, 3, 5 and 8 post-injection while those from the non-injected group were counted on Day 1 only. Haemolymph samples $(100 \mu l)$ were taken with a sterile needle $(18 \mathrm{G} 1 / 2,1.2 \times 40 \mathrm{~mm})$ from just under the soft ventral cuticle of the abdomen and immediately fixed with $10 \%$ formalin in $0.15 \mathrm{M}$ $\mathrm{NaCl}$. Haemocytes were immediately counted in a haemocytometer.

Statistical analysis: The data from haemocyte counts were examined for significance either by 1-way ANOVA when several groups were compared or by a $t$-test when only 2 groups were compared. Differences were considered statistically significant at $\mathrm{p} \leq 0.05$.

Results. Gross pathology: Typical gross signs of WSSV infection in shrimp (i.e., appearance of white spots in the cuticle, overall reddish body coloration, or both) were not found in the crayfish injected with WSSV. Gross signs of WSSV infection in crayfish were (1) reddish haemolymph, (2) a significantly delayed clotting reaction (Hall et al. 1999, Sritunyalucksana \& Söderhäll 2000), (3) a reduction in activity and locomotion, and (4) a weak response to stimulation. Crayfish usually started to die from Days 7 to 8 post-injection and all crayfish were dead at Day 10 post-injection.

Histopathological observations: Lesions caused by viral injection were observed in the gill lamellae (Fig. 1a), cuticular epidermis around the stomach (Fig. 1b), nuclei of adipose connective tissue (Fig. 1c), haematopoietic tissue (Fig. 1d), heart and haemocytes of all viral injected crayfish, but no affected cells were found in the hepatopancreatic tubules. The target tissues revealed foci of cells with enlarged nuclei that contained marginated chromatin separated from central, homogeneous, eosinophilic regions by an unstained ring at the early stage of infection (Fig. 1b,d, white arrowheads). These intranuclear, eosinophilic inclusions subsequently expanded to meet the marginated chromatin (Fig. 1a to d, black arrowheads). In moribund crayfish, these tissues displayed high numbers of affected nuclei.

Production of a probe by PCR and DNA sequence analysis: The DNA purified from gill tissue of virusinjected crayfish was used as a template for production of a probe by PCR. Electrophoresis of the PCR product showed a discrete band of approximately 1500 base pairs. These results indicated a successful amplification of the DNA fragment (Fig. 2) and the product was named cfWSSV. The cfWSSV fragment from the PCR amplification was sequenced and verified as a partial sequence of WSSV of penaeid shrimp (GenBank accession No. AF178573).

In situ hybridisation assay: The probe cfWSSV was shown to be specific for WSSV because it produced a positive reaction as indicated by a strong signal in affected cells of various target tissues after in situ hybridisation (Fig. 1e). No reactions were observed in tissues or cells of sham-injected or uninjected control crayfish (Fig. 1f) or in the tissue from virus-injected crayfish when the in situ hybridisation protocol was followed without the cfWSSV probe.

Circulating haemocyte counts upon viral infection: The numbers of both granular cells and total haemocytes in the haemolymph of sham-injected crayfish increased with a peak on Day 3, then declined near to the numbers of haemocytes of non-injected crayfish by Day 5. By contrast, granular cell numbers of WSSVinjected crayfish were slightly higher on Day 1 and continuously increased thereafter with a peak on Day 3. They subsequently stayed higher than the numbers of sham-injected control crayfish. The total haemocyte count (THC) of the virus-injected group was not significantly different from the THC of the non-injected crayfish ( $p>0.05$, Fig. 3), whereas the THC of the sham-injected control group was significantly higher than that of the non-injected group only on Day 3 ( $p=0.05$, Fig. 3 ). By contrast, the granular cell number in the virus-injected group was significantly higher than that of the non-injected group from Day 3 to Day 8 ( $p<0.01$, Fig. 3 ), whereas the granular cell number of the sham-injected group was significantly higher than that of the non-injected group only on Day 3 ( $p<0.01$, Fig. 3$)$.

Comparison between the virus-injected group and the sham-injected group showed that the number of granular cells was significantly higher in the WSSVinjected group from Days 5 to 8 ( $p \leq 0.05$, Fig. 3). However, the percentage of granular cells after injection with or without WSSV was significantly higher than that in the non-injected crayfish from Days 1 to 8 ( $p<$ 0.001, Fig. 4). Comparison between the virus-injected group and the sham-injected group showed that the granular cell proportion of the virus-injected group was significantly higher from Days 3 to 8 ( $p<0.01$, Fig. 4 ). 

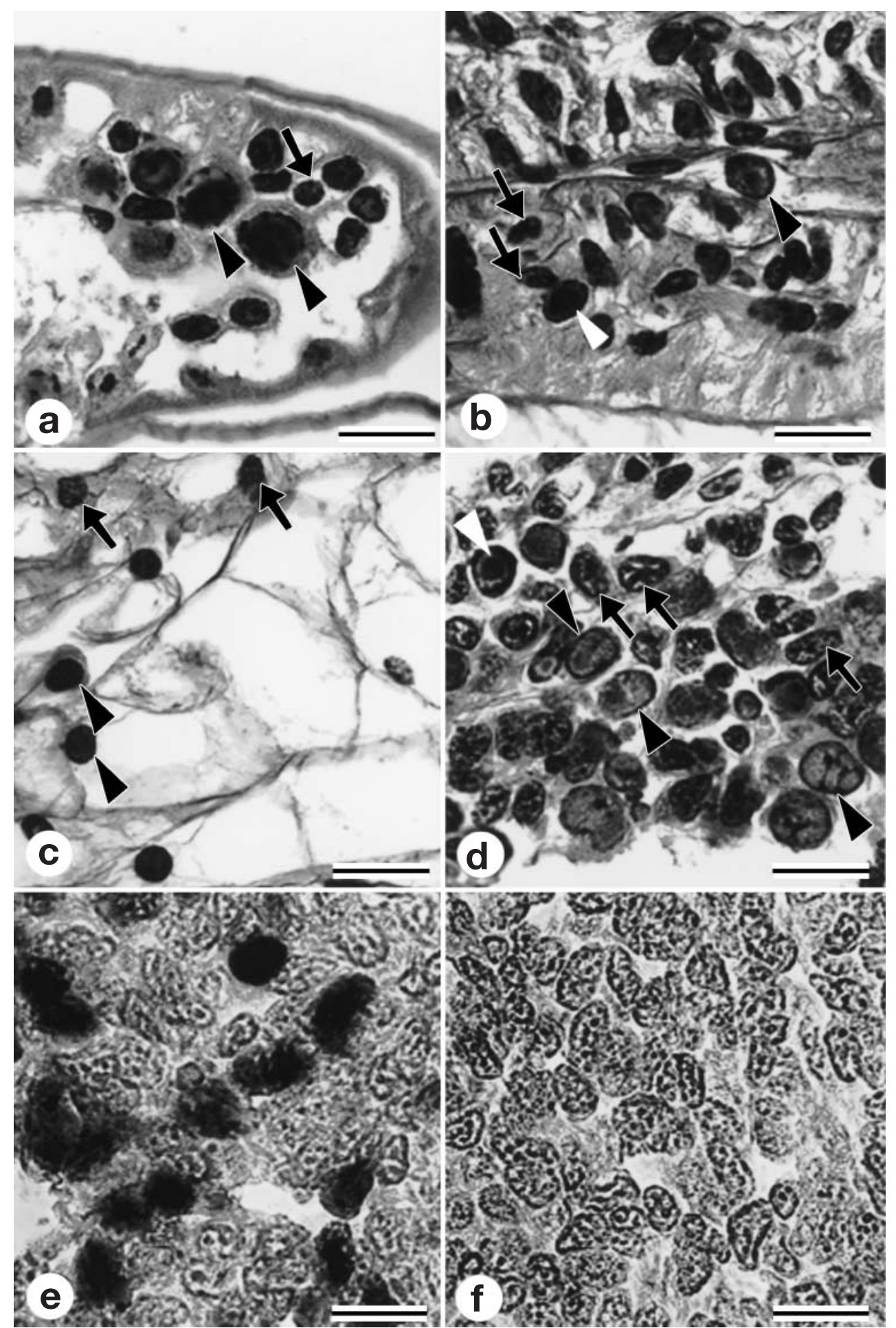

Fig. 1. Histopathology in target tissues from experimentally white spot syndrome virus (WSSV)-infected freshwater crayfish Pacifastacus leniusculus. Haematoxylin and eosin staining (a to d) revealed the characteristics of WSSV infection including enlarged nuclei with marginated chromatin, and central, homogeneous, eosinophilic inclusions (black arrowheads). Note an eosinophilic inclusion separated from the marginated chromatin by an unstained zone (white arrowheads). Gill lamellae (a), cuticular epithelium (b), adipose connective tissue (c) and haematopoietic tissue (d) show enlarged nuclei (black arrowheads) in most cells and normal nuclei (black arrows) in only a few. In situ hybridisation assay (e,f) of haematopoietic tissue from Day 8 shows a positive hybridisation reaction (dark nuclei) from virus-injected crayfish (f) and a negative reaction (no dark nuclei) from sham-injected crayfish (e). Scale bars $=10 \mu \mathrm{m}$ 


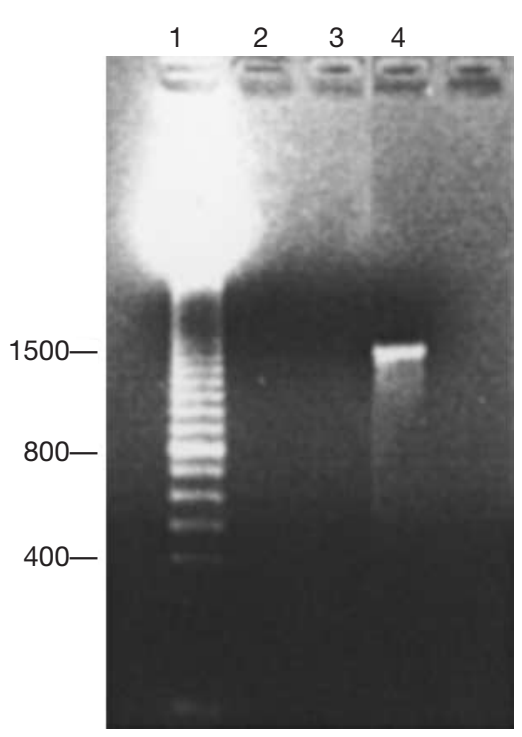

Fig. 2. Agarose gel showing a specific WSSV DNA fragment from polymerase chain reaction amplification using a DNA template from gills of virus-infected crayfish (lane 4). The negative controls (lanes 2 and 3) are distilled water and DNA from non-infected gills, respectively. Molecular weight markers (100 base pair ladder) are shown in lane 1

Discussion. The present study clearly shows that freshwater crayfish is one among many species of crustaceans susceptible to WSSV. Therefore, it is important to emphasise the risk of WSSV spread in European countries where it may have direct effects on native crayfish populations.

The histopathological study of organs and tissues in WSSV-injected crayfish revealed pathology similar to that of WSSV-infected penaeid shrimp (Chou et al. 1995, Huang et al. 1995, Durand et al. 1997, Y. G.

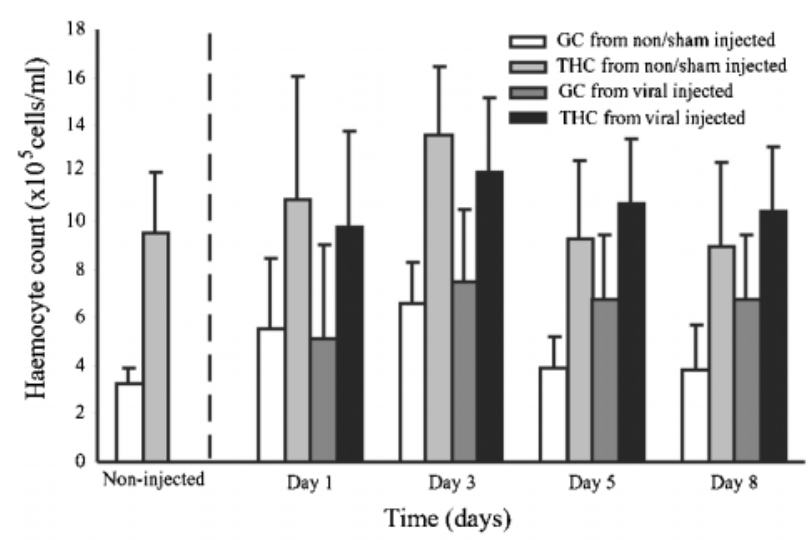

Fig. 3. Granular cell counts (GC) and total haemocyte counts (THC) in the haemolymph of injected and non-injected crayfish at different time intervals. The vertical bars represent the standard deviation of the means $(n=8)$

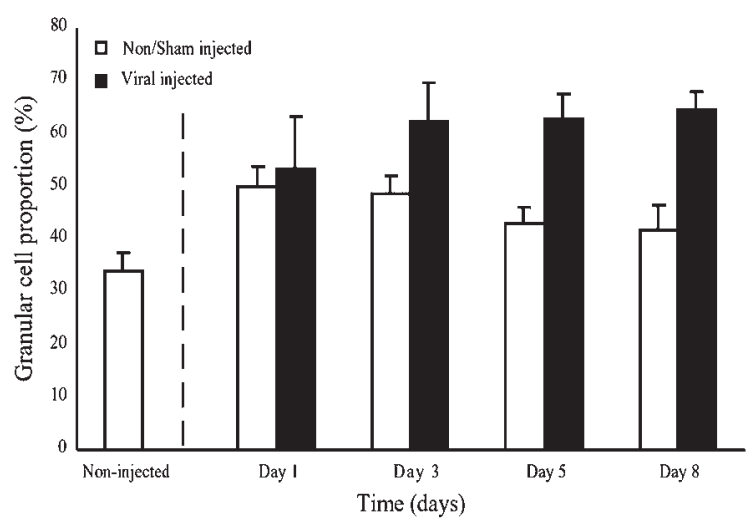

Fig. 4. Proportion of granular cells (\%) in virus-infected crayfish in comparison with sham-injected and non-injected crayfish. Vertical bars represent the standard deviation of the means $(\mathrm{n}=8)$

Wang et al. 1999). In all moribund crayfish, target organs were heavily infected with WSSV, and the high incidence of affected cells throughout the organ probably led finally to death through loss of organ function. However, the epithelial cells of tubules in the hepatopancreas were not affected with WSSV even when the crayfish were moribund. This observation was consistent with a previous report of Y. G. Wang et al. (1999) that the hepatopancreatic epithelial cells of Penaeus monodon are not infected by WSSV. The prominent gross signs of WSSV infection in penaeid shrimp (white spots in the cuticle and reddish body colour) were not seen on crayfish. This may have been due to the thickness of the cuticle, and its dark colour due to melanin pigment.

The results from in situ hybridisation in various tissues supported the results for viral infection based on histopathological observations with H\&E staining. The positive reaction in affected cells revealed that the cfWSSV used in this study was specific to WSSV and did not cross-react with uninfected cells or normal tissue. Furthermore, there were variations in signal intensity among the affected cells that probably depended on the stage of infection. Specifically, affected cells in the early stage of infection (i.e., with enlarged nuclei and intranuclear eosinophilic inclusions separated from marginated chromatin by an unstained space) gave a lightly positive reaction while later stage nuclei with full intranuclear eosinophilic inclusions or very dense inclusions gave stronger positive reactions.

It may be assumed that injection of gill tissue homogenates in L15 medium with or without WSSV would stimulate crayfish cellular defence mechanisms since the homogenates would contain foreign molecules. This might be one reason for higher granular cell num- 
bers from Days 1 to 3 in the injected groups. However, the elevated granular cell numbers in sham-injected crayfish returned to the level of uninfected animals at $5 \mathrm{~d}$ post-injection, whereas those of the virus-injected crayfish remained elevated until death or the end of the test period. This clearly showed that normal haemocyte balance was rapidly restored after sham injection but not after virus injection. Since the THCs remained unchanged, the relative proportion of granular cells increased. There are several possible explanations for this. For example, it is possible that granular cells are more resistant to viral infection than nongranular cells and that a longer period is required for them to be destroyed by the virus. Indeed, C. H. Wang et al. (2000) have shown from transmission electron microscopy of WSSV-infected primary, lymphoid organ cell cultures that $18 \%$ of fibroblast-like cells were infected followed by $11 \%$ of adipose cells, $8 \%$ of reticular cells and $6 \%$ of granular cells. Another possible explanation arose from our histopathological studies, where we found that haematopoietic tissue was a heavily infected target for WSSV. Since haematopoietic tissue renews haemocytes by continuous release into the haemolymph (Söderhäll \& Cerenius 1992), WSSV may affect haematopoietic tissue development and lead to changes in the proportions of different circulating blood cell types. Yet another possible explanation might be the presence of an antiapoptosis gene in WSSV, similar to those found in the DNA virus of the family Baculoviridae (Clem et al. 1991). A tentative product of such an antiapoptosis gene might be able to prevent apoptosis and allow viral replication to occur in some cells but not others. This latter possibility may be less likely now that WSSV is known to be only distantly related to the baculoviruses (Tsai et al. 2000, Liu et al. 2001), contrary to the conjecture in earlier publications that it is closely related (e.g., Wongteerasupaya et al. 1995). In any case, further studies are necessary to determine the susceptible level to WSSV among haemocyte types, even though haemocytes have been reported to be targets of WSSV in penaeid shrimp (Durand et al. 1996, Y. G. Wang et al. 1999, C. H. Wang et al. 2000) and crabs (Kanchanaphum et al. 1998).

Acknowledgements. This work was supported by a travel grant from EU-INCO and by a grant from the Swedish Research Council for Agriculture and Forestry to K.S. Anbar Khodabandeh is acknowledged for technical assistance.

\section{LITERATURE CITED}

Bell TA, Lightner DV (1998) A handbook of normal penaeid shrimp histology. World Aquaculture Society, Baton Rouge, LA

Chang PS, Chen HC, Wang YC (1998) Detection of white spot syndrome associated baculovirus in experimentally in- fected wild shrimp, crab and lobsters by in situ hybridization. Aquaculture 164:233-242

Chou HY, Huang CY, Wang CH, Chiang HC, Lo CF (1995) Pathogenicity of a baculovirus infection causing white spot syndrome in cultured penaeid shrimp in Taiwan. Dis Aquat Org 23:165-173

Clem RJ, Fechheimer M, Miller LK (1991) Prevention of apoptosis by a baculovirus gene during infection of insect cells. Science 254:1388-1390

Durand S, Lightner DV, Nunan LM, Redman RM, Mari J, Bonami JR (1996) Application of gene probes as diagnostic tools for white spot baculovirus (WSBV) of penaeid shrimp. Dis Aquat Org 27:59-66

Durand S, Lightner DV, Redman RM, Bonami JR (1997) Ultrastructure and morphogenesis of white spot syndrome baculovirus (WSSV). Dis Aquat Org 29:205-211

Flegel TW (1997) Special topic review: major viral diseases of the black tiger prawn (Penaeus monodon) in Thailand. World J Microbiol Biotech 13:433-442

Flegel TW, Fegan DF, Sriurairatana S (1995) Environmental control of infectious disease in Thailand. In: Browdy CL, Hopkins JS (eds) Swimming through troubled water. Proceeding of special session on shrimp farming, Aquaculture '95. World Aquaculture Society, Baton Rouge, LA, p 65-79

Hall M, Wang R, van Antwerpen R, Sottrup-Jensen L, Söderhäll K (1999) The crayfish plasma clotting protein: a vitellogenin-related protein responsible for clot formation in crustacean blood. Proc Natl Acad Sci USA 96:1965-1970

Huang J, Song XL, Yu J, Yang CH (1995) Baculoviral hypodermal and hematopoietic necrosis-study on the pathogen and pathology of the explosive epidemic disease of shrimp. Mar Fish Res 16:1-10

Inouye $\mathrm{K}$, Miwa $\mathrm{S}$, Oseko, N, Nakano H, Kimura T, Momoyama K, Hiraoka M (1994) Mass mortalities of cultured kuruma shrimp Penaeus japonicus in Japan in 1993: electron microscopic evidence of the causative virus. Fish Pathol 29:149-158

Kanchanaphum P, Wongteerasupaya C, Sititidilokratana N, Boonsaeng V, Panyim S, Tassanakajon A, Withyachumnarnkul B, Flegel TW (1998) Experimental transmission of white spot syndrome virus (WSSV) from crabs to shrimp Penaeus monodon. Dis Aquat Org 34:1-7

Lightner DV, Redman RM, Poulos BT, Nunan LM, Mari JL, Hasson KW (1997) Risk of spread of penaeid shrimp viruses in the Americas by the international movement of live shrimp for aquaculture and frozen shrimp for commodity markets. Rev Sci Tech Off Int Epizoot 16:146-160

Liu WJ, Yu HT, Peng SE, Chang YS, and 9 others (2001) Cloning, characterization and phylogenetic analysis of a shrimp white spot syndrome virus (WSSV) gene that encodes a protein kinase. Virology (in press)

Lo CF, Leu JH, Ho CH, Chen CH and 8 others (1996) Detection of baculovirus associated with white spot syndrome virus (WSBV) in penaeid shrimps using polymerase chain reaction. Dis Aquat Org 25:133-141

Lo CF, Hsu HC, Tsai MF, Ho CH, Peng SE, Kou GH, Lightner DV (1999) Specific genomic DNA fragment analysis of different geographical clinical samples of shrimp white spot syndrome virus. Dis Aquat Org 35:175-185

Mohan CV, Shankar KM, Kulkarni S, Sudha PM (1998) Histopathology of cultured shrimp showing gross signs of yellow head and white spot syndrome during 1994 India epizootics. Dis Aquat Org 34:9-12

Momoyama K, Hiraoka M, Nakano H, Inouye K, Oseko N (1994) Mass mortalities of cultured kuruma shrimp, Penaeus japonicus, in Japan in 1993: histopathological study. Fish Pathol 29:141-148 
Nakano H, Koube H, Umezawa S, Momoyama K, Hiraoka M, Inouye K, Oseko N (1994) Mass mortalities of cultured Kuruma shrimp, Penaeus japonicus, in Japan in 1993: epizootiological survey and infection trials. Fish Pathol 29:135-139

Nunan LM, Poulos BT, Lightner DV (1998) The detection of white spot syndrome virus (WSSV) and yellow head virus (YHV) in imported commodity shrimp. Aquaculture 160: $19-30$

Park JH, Lee YS, Lee S, Lee Y (1998) An infectious viral disease of penaeid shrimp newly found in Korea. Dis Aquat Org 34:71-75

Peng SE, Lo CF, Ho CH, Chang CF, Kou GH (1998) Detection of white spot baculovirus (WSBV) in giant freshwater prawn, Macrobrachium rosenbergii, using polymerase chain reaction. Aquaculture 164:253-262

Poulos BT, Pantoja CR, Bradley-Dunlop D, Aguilar J, Lightner DV (2001) Development and application of monoclonal antibodies for the detection of white spot syndrome virus of penaeid shrimp. Dis Aquat Org 47:13-23

Söderhäll K, Cerenius L (1992) Crustacean immunity. Annu Rev Fish Dis 2:3-23

Söderhäll K, Cerenius L (1999) The crayfish plague fungus: history and recent advances. Freshw Crayfish 12:11-35

Sritunyalucksana K, Söderhäll K (2000) The proPO and clotting system in crustaceans. Aquaculture 191:53-69

Supamattaya K, Hoffmann RW, Boonyaratpalin S, Kanchanaphum P (1998) Experimental transmission of white spot syndrome virus (WSSV) from black tiger shrimp Penaeus monodon to the sand crab Portunus pelagicus, mud crab Scylla serrata and krill Acetes sp. Dis Aquat Org 32:79-85

Takahashi Y, Itami T, Kondo M, Maeda M, Fujii R, Tomonaga S, Supamattaya K, Booyaratpalin S (1994) Electron microscopic evidence of bacilliform virus infection in Kuruma shrimp (Penaeus japonicus). Fish Pathol 29:121-125

Editorial responsibility: Timothy Flegel,

Bangkok, Thailand
Tsai MF, Yu HT, Tzeng HF, Leu JH and 7 others (2000) Identification and characterization of a shrimp white spot syndrome virus (WSSV) gene that encodes a novel chimeric polypeptide of cellular-type thymidine kinase and thymidylate kinase. Virology 277:100-110

Wang $\mathrm{CH}$, Lo CF, Leu JH, Chou CM and 6 others (1995) Purification and genomic analysis of baculovirus associated with white spot syndrome virus (WSBV) of Penaeus monodon. Dis Aquat Org 23:239-242

Wang CH, Yang HN, Tang CY, Lu CH, Kou GH, Lo CF (2000) Ultrastructure of white spot syndrome virus development in primary lymphoid organ cell culture. Dis Aquat Org 41:91-104

Wang Q, White BL, Redman RM, Lightner DV (1999) Per os challenge of Litopenaeus vannamei postalarvae and Farfantepenaeus duorarum juveniles with six geographic isolates of white spot syndrome virus (WSSV). Aquaculture 170:179-194

Wang Q, Nunan LM, Lightner DV (2000) Identification of genomic variations among geographic isolates of white spot syndrome virus using restriction analysis and Southern blot hybridization. Dis Aquat Org 43:175-181

Wang YC, Lo CF, Chang PS, Kou GH (1998) Experimental infection of white spot baculovirus in some cultured and wild decapods in Taiwan. Aquaculture 164:221-231

Wang YG, Hassan MD, Shariff M, Zamri SM, Chen X (1999) Histopathology and cytopathology of white spot syndrome virus (WSSV) in cultured Penaeus monodon from peninsular Malasia with emphasis on pathogenesis and the mechanism of white spot formation. Dis Aquat Org. 39:1-11

Wongteerasupaya C, Vickers JE, Sriurairatana S, Nash GL and 6 others (1995) A non-occluded, systemic baculovirus that occurs in cells of ectodermal and mesodermal origin and causes high mortality in the black tiger prawn Penaeus monodon. Dis Aquat Org 21:69-77

Submitted: March 16, 2001; Accepted: August 28, 2001 Proofs received from author(s): October 18, 2001 